ACTA THERIOLOGICA

Vol. 33, 30: 415-434, 1988

\title{
Observations on an Otter Population in Decline
}

\author{
Sheila M. MACDONALD \& Christopher F. MASON
}

\begin{abstract}
Macdonald S.M. \& Mason Ch. F., 1988: Observations on an otter population in decline. Acta theriol., 33, 30: 415-434. [With 1 Table \& 9 Figs].

The distribution of otter signs on the catchment of the River Teme, United Kingdom, over a ten year period indicated that the range of the species, already limited at the start of the study in 1977, declined further over subsequent years. Otters became restricted to the upper reaches of the catchment. Evidence is presented that contamination with organochlorines (which can be extracted from spraints) may have been responsible for the decline. Reasons for a possible increase in otter distribution during the final years of the study are discussed. Regular observations of sprainting sites on the River Clun (a Teme tributary) showed that otter signs showed a negative exponential loss rate with time, $90 \%$ still surviving two weeks after deposition. The level of marking on the Clun suggested a low otter population and the clear seasonality in sprainting activity typical of thriving populätions was not detected. Sprainting activity declined during the study period. There was, however, a seasonal pattern in the deposition of different types of signs. Most signs of otters on the Clun were located in the central reaches of the river, which had
\end{abstract} the greatest amount of bankside cover.

[Department of Biology, University of Essex, Wivenhoe Park, Colchester CO4 $3 \mathrm{SQ}$, U.K].

\section{INTRODUCTION}

The otter Lutra lutra (Linnaeus, 1758) has declined substantially in numbers in Western Europe over the last three decades and is now absent from large areas of its former range (Mason \& Macdonald, 1986). Much of our ecological knowledge of the species stems from the pioneering studies of Erlinge (1967a, b; 1968a, b) in Sweden, but the population decline has stimulated several recent studies in Britain (e.g. Jenkins, 1980; Jenkins \& Burrows, 1980; Jenkins \& Harper, 1980; Green et al., 1984; Macdonald \& Mason, 1987). All of this work has concerned thriving otter populations, not surprisingly in view of the generally low population density and largely nocturnal behaviour of the species. Nevertheless, the ecology of those populations under stress may be of especial importance to people concerned with the conservation of otters.

We report here observations, made over a ten year period, on a declining population of otters in the catchment of the River Teme, 
which flows from Powys, Wales, into west midland England (counties of Shropshire, Hereford and Worcester), United Kingdom. We demonstrate a gradual restriction in range of the species, describe patterns of marking activity within the study area and explore reasons for the decline of otters within the catchment.

\section{STUDY AREA AND METHODS}

The River Teme (Fig. 1) rises at an altitude of $300 \mathrm{~m}$ in moorland in Powys, central Wales, and flows for $130 \mathrm{~km}$ to discharge into the River Severn below Worcester. Five major tributaries (with long term average flows greater than $5 \mathrm{~m}^{3} \mathrm{~s}^{-1}$ ) also rise in upland moorland and grassland and have a combined length of approximately $170 \mathrm{~km}$.

The catchment is predominantly agricultural, with some deciduous woodland and conifer plantations. The upper catchment, above the confluence with the Ledwyche Brook (see Fig. 1) is primarily pasture for sheep and cattle grazing. The lower catchment is mixed farming. There are several small riverside towns, the largest being Ludlow (population 8,000). The water is classed as unpolluted throughout. Further details can be found in Macdonald et al. (1978).

The study was conducted between May 1977 and September 1987 inclusive. Surveys for otters involved recording the number and locations of signs of the species. Signs included spraints (faeces containing food remains), "smears" (tar-like secretions lacking solid food remanis) and "jellies" (jelly-like secretions of various colours with the characteristic otter odour). This terminology follows Macdonald \& Mason (1987). A sprainting site is defined broadly as a site which has been marked with spraints, smears or jelly. Spraint sites may contain a number of individual signs. In addition, footprints of otters in sinow, mud or sand were recorded and their breadth at the broadest span, to include 5 toes,

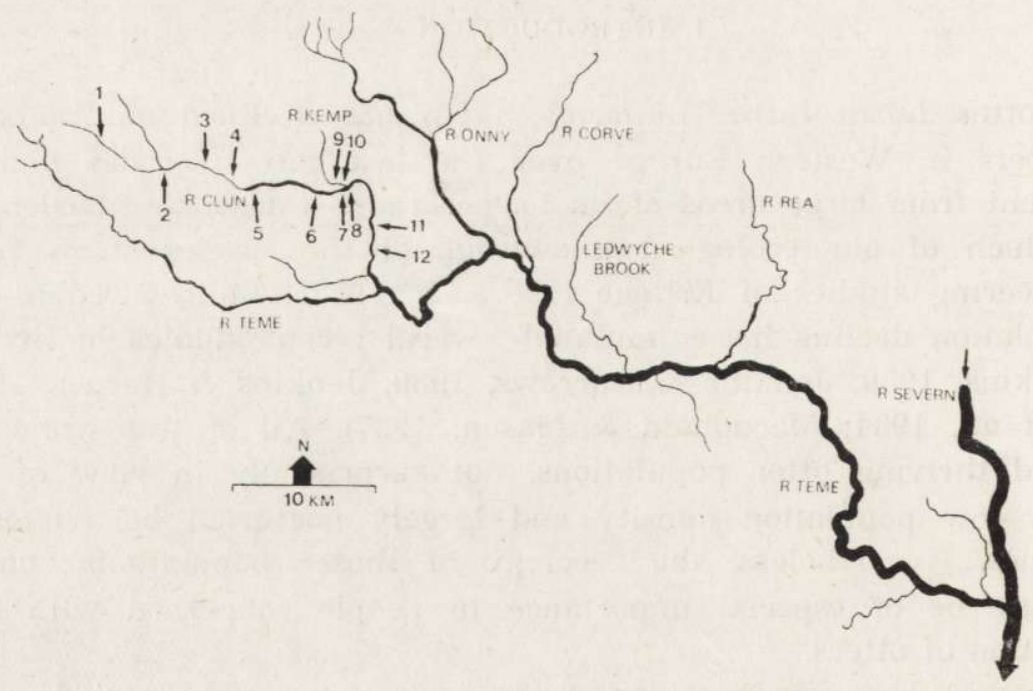

Fig. 1. The catchment of the River Teme, showing the position of the 12 intensive monitoring sites on its tributary, the River Clun. 
measured to the nearest millimetre. Occasionally, otters clawed at the substrate at spraint sites, scratching up mud, sand or moss and these "scratchings" were recorded. Detailed descriptions of otter signs are given in Mason and Macdonald (1986).

The entire length of the River Teme $(130 \mathrm{~km})$ was walked between May and August 1977 and all signs of otters were recorded, while the land around all bridges on all tributaries (with a long-term average flow greater than $3 \mathrm{~m}^{3}$ $\mathrm{s}^{-1}$ ) was searched during the same period. This established the distribution of otter signs within the catchment in 1977 (see Macdonald et al., 1978 for details). From 1980 to 1984 inclusive the rivers of the lower catchment (Corve, Ledwyche, Rea and the Teme below Ludlow) were surveyed annually using the ,standard British survey method" (i.e. a maximum of $600 \mathrm{~m}$ of one bank searched, see Macdonald 1983 for details) at each bridge while more frequent visits to known sprainting sites were made to confirm distribution. The Onny and the Teme above Ludlow were searched systematically on a quarterly basis for signs of otters from 1980 to 1984 inclusive and known spraint sites were visited at more regular intervals throughout the period. Biannual checks were made from 1985 to 1987. Known sprainting sites throughout the whole catchment were again surveyed in September 1987 and the lower Teme was searched in April 1988.

The River Clun, another tributary of the upper Teme, was selected for more intensive study. In early March 1978 the entire length of the Clun $(32 \mathrm{~km})$ was walked and all signs of otters were recorded. From the distribution of signs found, twelve representative sites (Fig. 1) were selected for regular monitoring and these were visited at approximately weekly intervals until March 1985 inclusive and all signs of otters were recorded. Irregular visits were then made until September 1987. Signs were marked with a small spot of cellulose paint to ensure they were not counted again in subsequent visits. On each visit the water level in the river was measured at a vertical staff gauge, permanently sited about $1 \mathrm{~km}$ upstream of site 11. Complete searches of the River Clun catchment, to confirm the representativeness of the selected sites, were undertaken in October/November 1979, February 1980 and December 1980. Extensive stretches of the river were searched for otters at frequent but irregular intervals throughout the study period.

Spraints, once deposited, begin to weather and decompose or are washed away in spates or by rainfall, so it was necessary to determine if the spraints counted at a site during a visit were a reliable sample of spraints deposited since the previous visit. To study the rate of loss, spraints found at all sites between August and December 1978 were marked with a small spot of cellulose paint, using different colours for successive weeks. The number of marked spraints remaining in each subsequent week was recorded.

Between March and June 1978, the entire length of the River Clun was walked and all trees (mature and sapling) growing on both banks were identifield and counted. Potential holts and lying-up (resting) sites for otters were recorded. Methods followed Macdonald et al. (1978) and Macdonald and Mason (1983). Additional potential holts and lying-up sites were recorded on subsequent visits to the river.

Organochlorine contaminants are considered to be the main reason for the steep decline in otter numbers in Britain (see Mason \& Macdonald, 1986, for review). No otters were found dead in our area during the study period to allow an assessment of pollutant burden in the population and this was therefore as- 
sessed indirectly by determining the concentrations of organochlorines in samples of fresh spraints. Spraints were collected from sites on the River Clun and les of fresh spraints. Spraints were collected from sites on the River Clun and River Teme between March 1984 and April 1985 inclusive. Spraints collected from individual sites on particular dates were bulked and wrapped in aluminium foil. They were stored deep-frozen prior to analysis. For comparison, samples were collected in a a similar way from the River Severn, Wales, known to support a thriving otter population (Macdonald \& Mason, 1987) between October 1984 and September 1986 and from the River Wissey, Norfolk, known to support a threatened population (pers. obs.), between April 1985 and May 1987.

In the laboratory samples were allowed to thaw. Organochlorines were then extracted following methods in FAO (1983) and samples were cleaned following methods in HMSO (1979). Analyses were carried out using a Carlo-Erba 4300 gas chromatograph, with a tritium electron capture detector and using a capillary column. The detection level was $0.01 \mathrm{mg} \mathrm{kg-1}$.

\section{RESULTS}

\subsection{Survey of the Teme Catchment}

The distribution of otter signs in the Teme catchment in 1977 and from 1980-1984 inclusive is shown in Fig. 2. Otters were considered not to be resident, but to be infrequent visititors to a river if signs were found on only one visit during a year and few known sprainting sites had been marked. If signs were found on more than one visit to a river and during the course of a year and a good proportion of known sprainting sites had been marked, it was considered that such stretches formed part of the home range of a resident otter. It can be seen that in 1977 the species had a restricted range in the catchment and that by 1980 the lower part of the catchment was largely deserted. Single spraints were found in January 1983 and October 1984 on the River Rea, but all other searches proved fruitless, suggesting sporadic visits by an animal from elsewhere in the catchment. Further losses in range occurred between 1981 affecting the River Onny. All searches of the Onny in 1982 and 1983 proved negative but in January 1984 sings were found at traditional sites and at a previously unmarked site almost to the source. Regular visits during the rest of the year revealed occasional signs in the lower sections of the river, suggesting that an animal from the Teme was sometimes using the river. Overall during the study period the species appeared to become restricted in its regular range to the Clun and adjacent istretches of the upper, Teme.

The upper Teme was monitored at least once every two months from 1980 to 1985 and then biannually until 1987. Throughout this period the species was present between Ludlow (at the confluence of the 
Corve, see Fig. 1) and Knighton (14 km above the confluence with the Clun), although marking was not consistent throughout the length. Tracks of cubs were found only in the spring of 1980. Signs of otter were found rarely and sporadically above and below this stretch of the Teme throughout the study period, but otters were thought not to be resident in these stretches.

A survey of known sprainting sites in September 1987 confirmed the continued presence of otters on the upper Teme and Clun. Signs of otters were also present on the Corve, where signs had never pre viously been found, the Onny, the Rea and the main river to the confluence with the Ledwyche (Fig. 1). In April 1988 signs were found on the main river $16 \mathrm{~km}$, but no further, below the confluence with the Rea (Fig. 1).

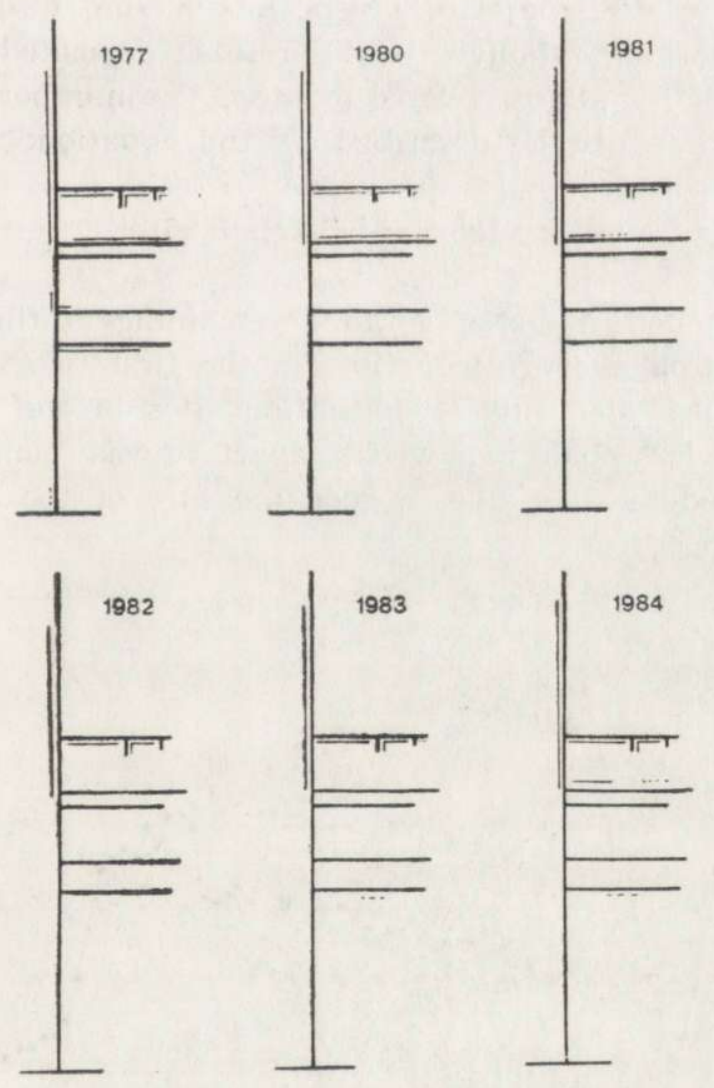

Fig. 2. Distribution of the otter in the Teme catchment, 1977-84. Solid lines indicate regular evidence of otters, dotted lines indicate infrequent occurrence. 


\subsection{Observations on River Clun}

On a full survey of the River Clun in early March 1978, prior to the stablishment of the intensive monitoring sites, a total of 33 sprainting sites were located. The twelve intensive monitoring sites there-1 fore represented a reasonable proportion of the total sites recorded and reflected the geographical distribution of those sites. On the other complete surveys of the catchment, the number of sprainting sites located varied between 18 (December 1980) and 65 (October 1979). It is clear from the full surveys of the Clun catchment and from frequent partial surveys involving stretches of river bank, that the overall level of marking by otters was low.

The time for disappearance of 92 marked spraints was recorded over the period August to December 1978. There was an exponential rate of loss, with the majority of spraints having disappeared within 13 weeks of marking, though two spraints, deposited in a sheltered hollow, persisted for almost twelve months. The number of spraints remaining with time can be described by the equation:

$$
s_{\mathrm{t}}=155.3 e^{-0.34 \mathrm{t}}\left(r^{2}=0.96\right)
$$

where $s_{\mathrm{t}}$ is the percentage of spraints remaining at time $t$. Less than $10 \%$ of spraints on average were lost in the first two weeks following marking. Because our visits to sprainting sites in the intensive study were generally less than two weeks apart it was concluded that the spraints recorded at sites were a good measure of the spraints deposited there by otters.

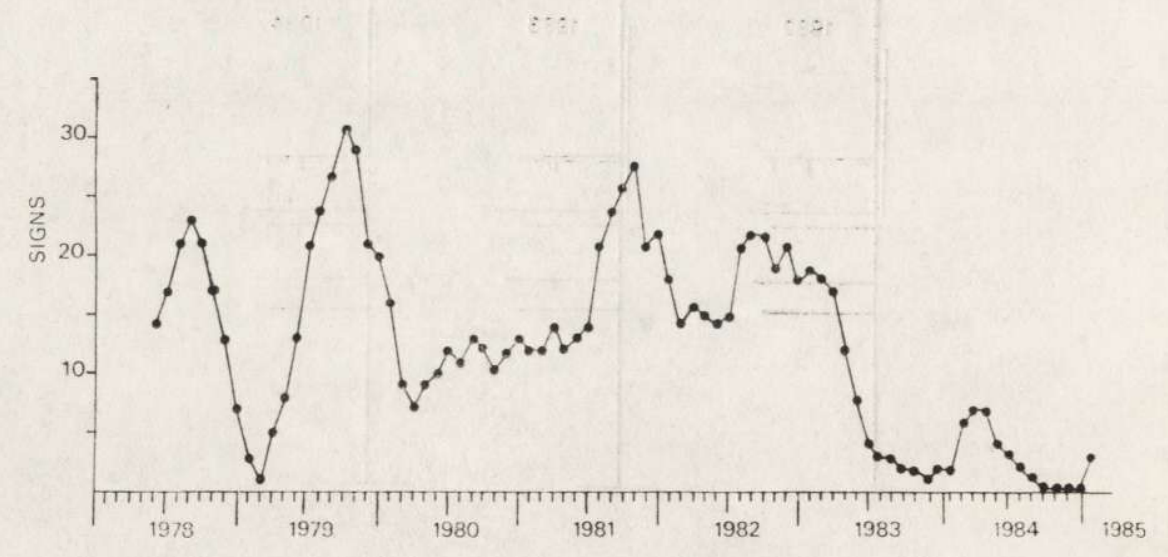

Fig. 3. Total number of signs (expressed as a five-point moving average) recorded at 12 sites on the River Clun, March 1978 - March 1985 inclusive. 
To examine trends in the level of sprainting activity on the 12 monitoring sites on the River Clun between March 1978 and March 1985 inclusive, monthly totals of signs were plotted as a five point moving average (Fig. 3). There were clear increases in marking level in summer/autumn in some years $(1978,1979,1981)$. A decrease in marking activity was apparent in the last two years of study and in many months during this period, no signs were found and searches at other sites also proved negative. It was concluded that otters were absent from the river for substantial lengths of time. Casual observations through 1985,1986 and 1987 , after the termination of the main part of this study, showed that otters were again present in the Clun catchment, though marking activity remained low.

The apparent seasonal pattern of marking in some years can be further examined by combining monthly totals over the seven year period (Fig. 4). Overall, 37\% of the signs were recorded in the three month period August to October. Water levels are generally higher in winter and may have influenced this apparent pattern of marking. Correlations were therefore made for each month between the number of signs recorded on a visit and the water level measured on the vertical staff gauge on that visit. There were significant negative corre-

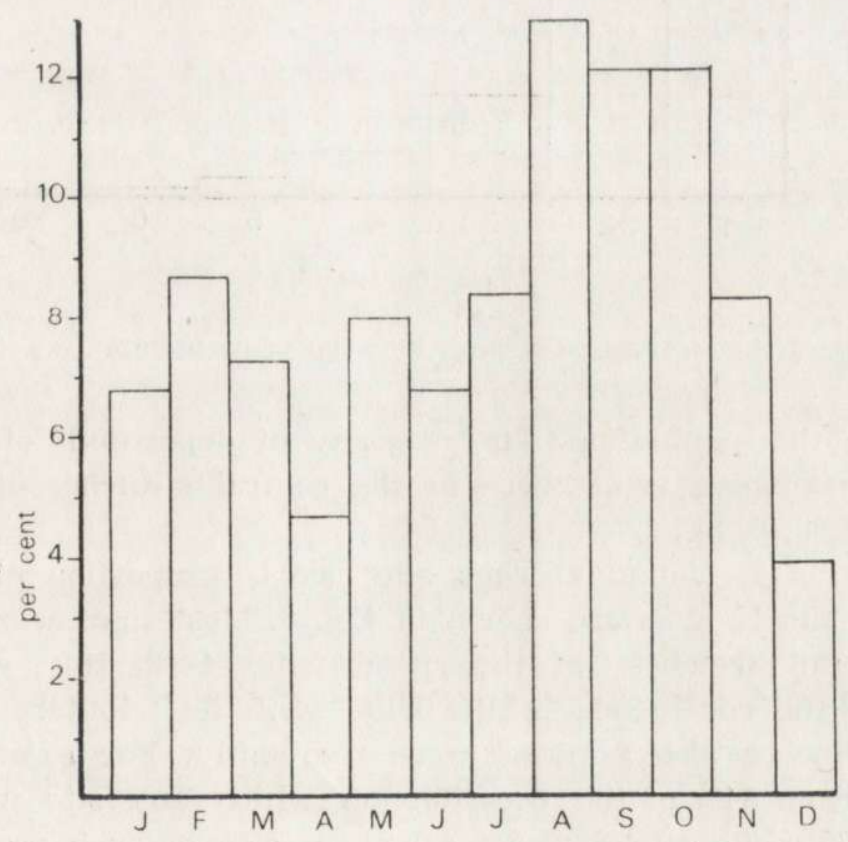

Fig. 4. Monthly frequency of occurrence of signs $(n=1064)$ at 12 sites on the Clun catchment March 1978 - February 1985 inclusive. 
lations between signs counted and water level in January, February, April $(p<0.05)$, March and August $(p<0.01)$. For these months signs recorded may be underestimates of signs deposited, but this seems unlikely to have influenced the overall general pattern of a late summer increase in marking activity.

The number of signs deposited at sprainting sites on the River Clun between monitoring visits is shown in Fig. 5 . In over $60 \%$ of cases only single signs were left, again indicative of a low level of

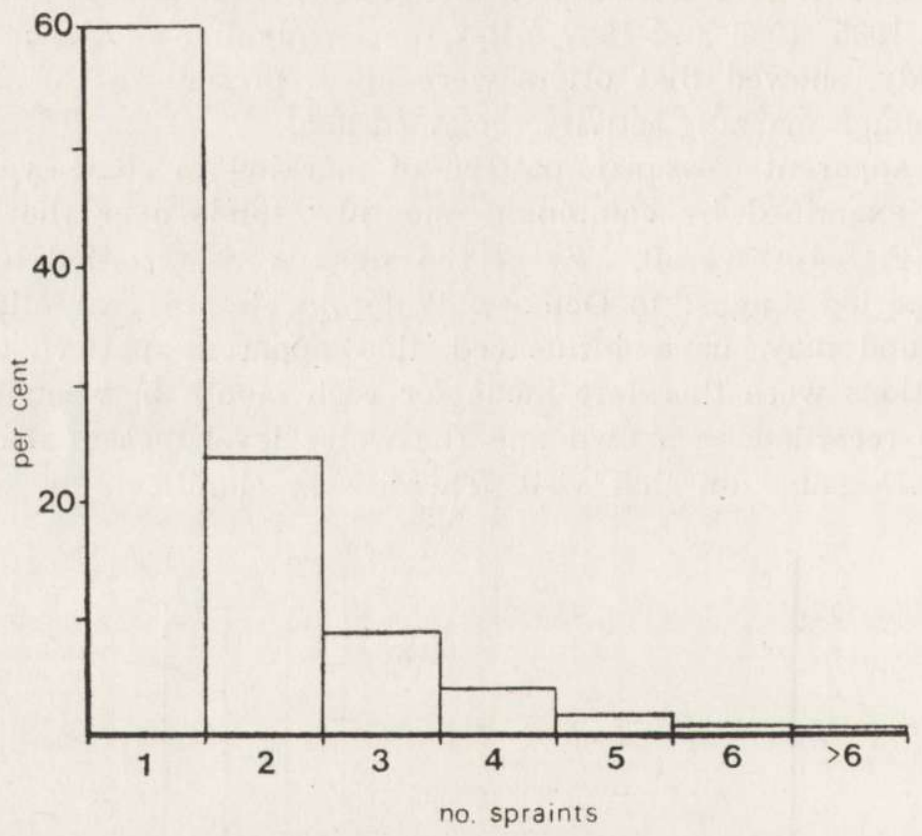

Fig. 5. Number of signs deposited at sites between visits $(n=625)$.

marking by this population. The majority of depositions of more than three signs between visits were in the central stretches of the study area (sites $4,5,6,8$ ).

The total signs found at each site as a proportion of all signs recorded at the 12 sites are shown in Fig. 6. Most signs were deposited in the central stretches of the river (sites $4-8,10$ ), with site 8, adjacent to the confluence of the Clun with its tributary the Kemp. These sites were also marked more frequently. For lexample, site 8 was marked on $64 \%$ of the occasions on which any site in the river was marked, while site 6 was marked on $49 \%$ of such occasions. The stretch of river between sites 4 and 8 would therefore seem to be the centre of activity of otters on the Clun. This centre of activity 
remained constant throughout the study period (Fig. 7), the majority of marking being concentrated at sites 6 and 8. During the latter part of the study, when the overall level of marking was sharply reduced, otters ceased sprainting on the upper stretches of the catchment.

The monthly occurrences of spraints, smears and jelly are shown in Fig. 8. There was a greater proportion of "smears" during spring, while "anal jelly" occurred mainly during the winter period. There was

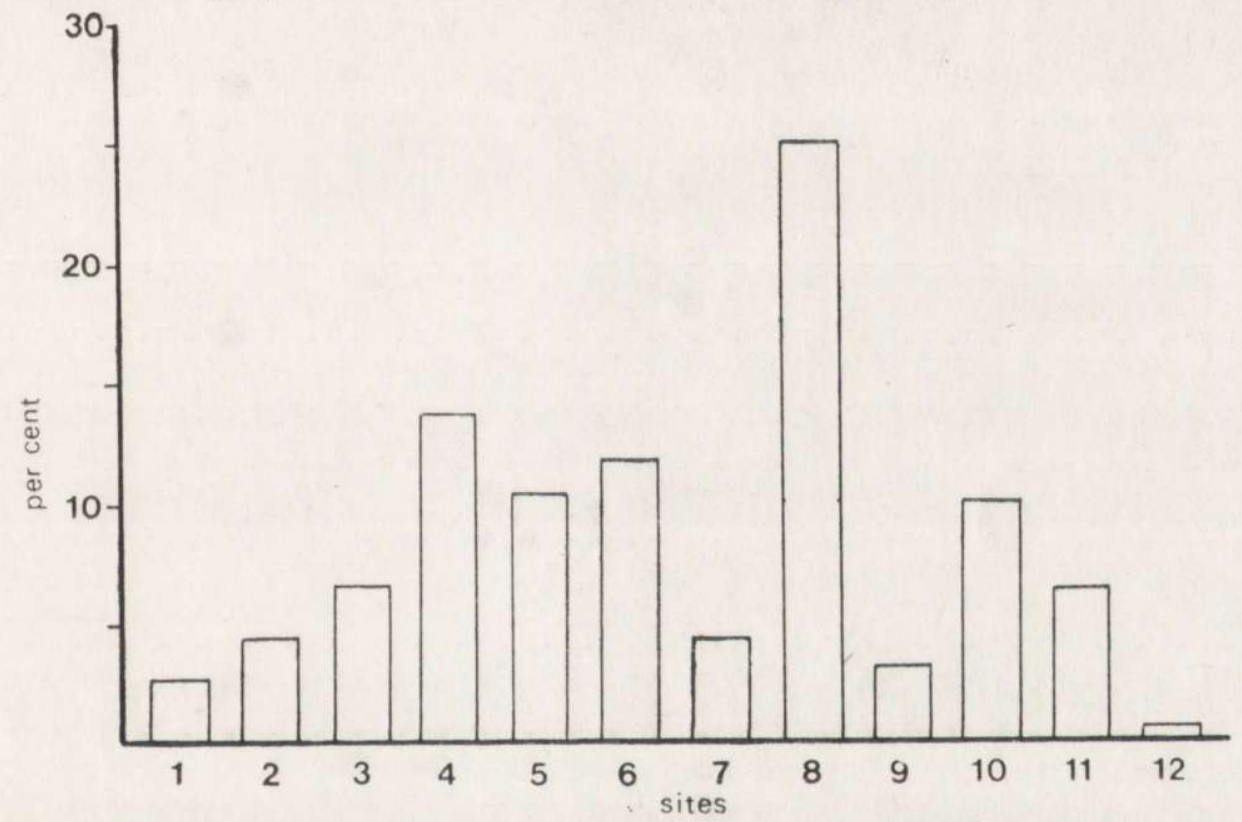

Fig. 6. Proportion of signs $(n=1064)$ deposited at each of 12 monitoring sites, River Clun, over a 7 year period from March 1978.

a significant negative relationship between the number of spraints and the number of "smears" $(r=0.55, p<0.05)$ i.e. as the overall level of marking declined, a greater proportion of signs were deposited as "smears". There was no relationship between the occurrence of "anal jelly" and that of spraints or "smears".

Otters also scratch the substrate with their claws. This activity was infrequent on the Clun, occurring most often in February, March and November ( $71.4 \%$ of occurrences) and was not recorded in January, April, May, August and September. The occurrence of scratching was significantly correlated with the appearance of "anal jelly" $(r=0.80$, $p<0.001$ ), suggesting that both of these signs are associated with a specific aspect of behaviour.

On the Clun tracks (measured across the widest part to include five toes) of probable females (or sub-adult males) were found regu- 


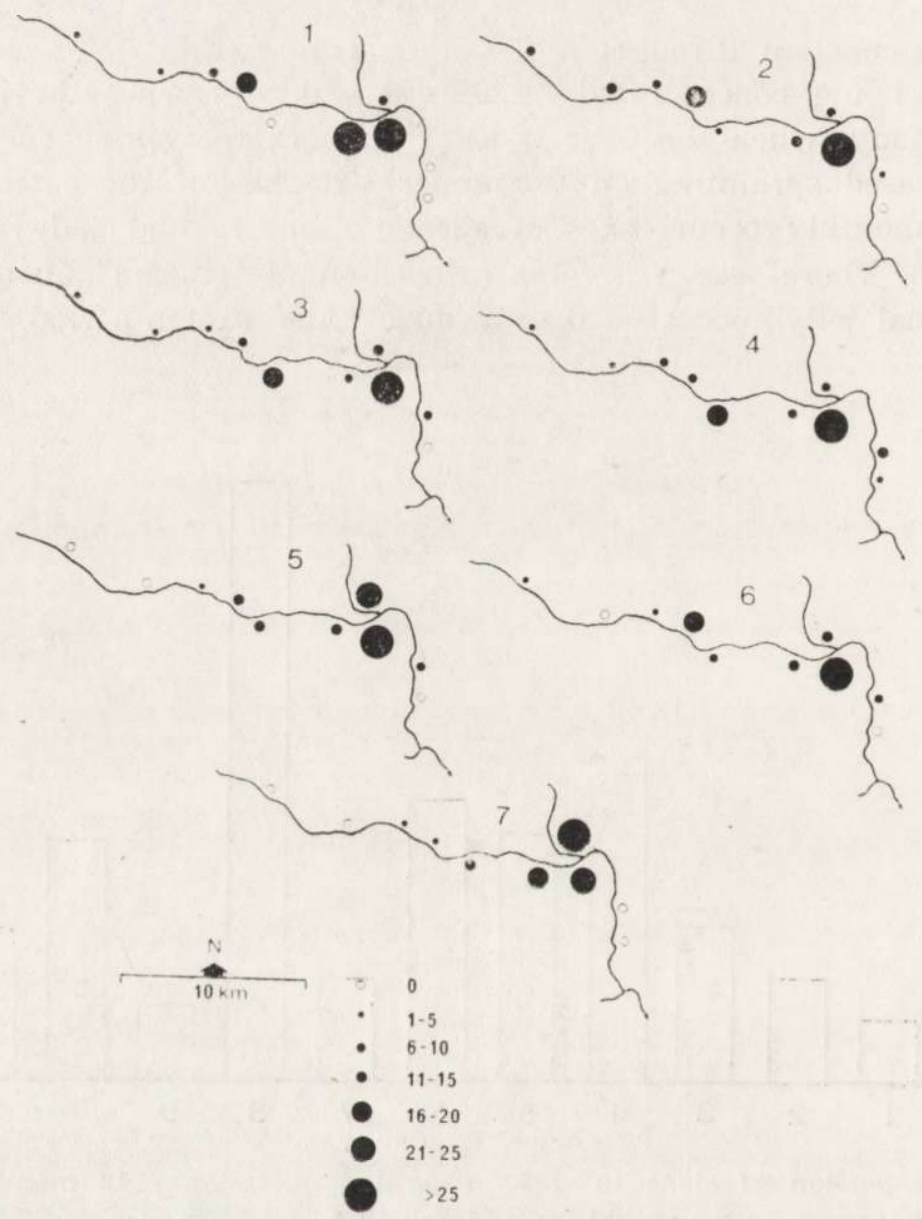

Fig. 8. Monthly occurrences of three categories of sign. Vertical hatching="anal over a period of 7 years (Year $1=$ March 1978-February 1979, etc.). Sites 7 and 8 , and 9 and 10 were combined because of their close proximity (see Fig. 1).

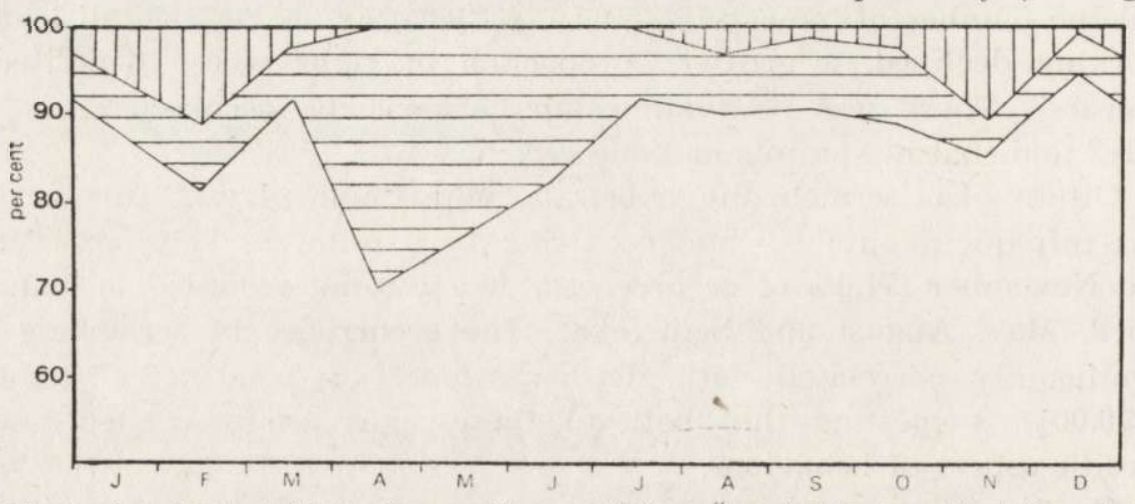

jelly", horizontal hatching="smears", remainder="spraints" (see text for details). Fig. 7. The percentage of signs recorded at monitoring sites on the River Clun 


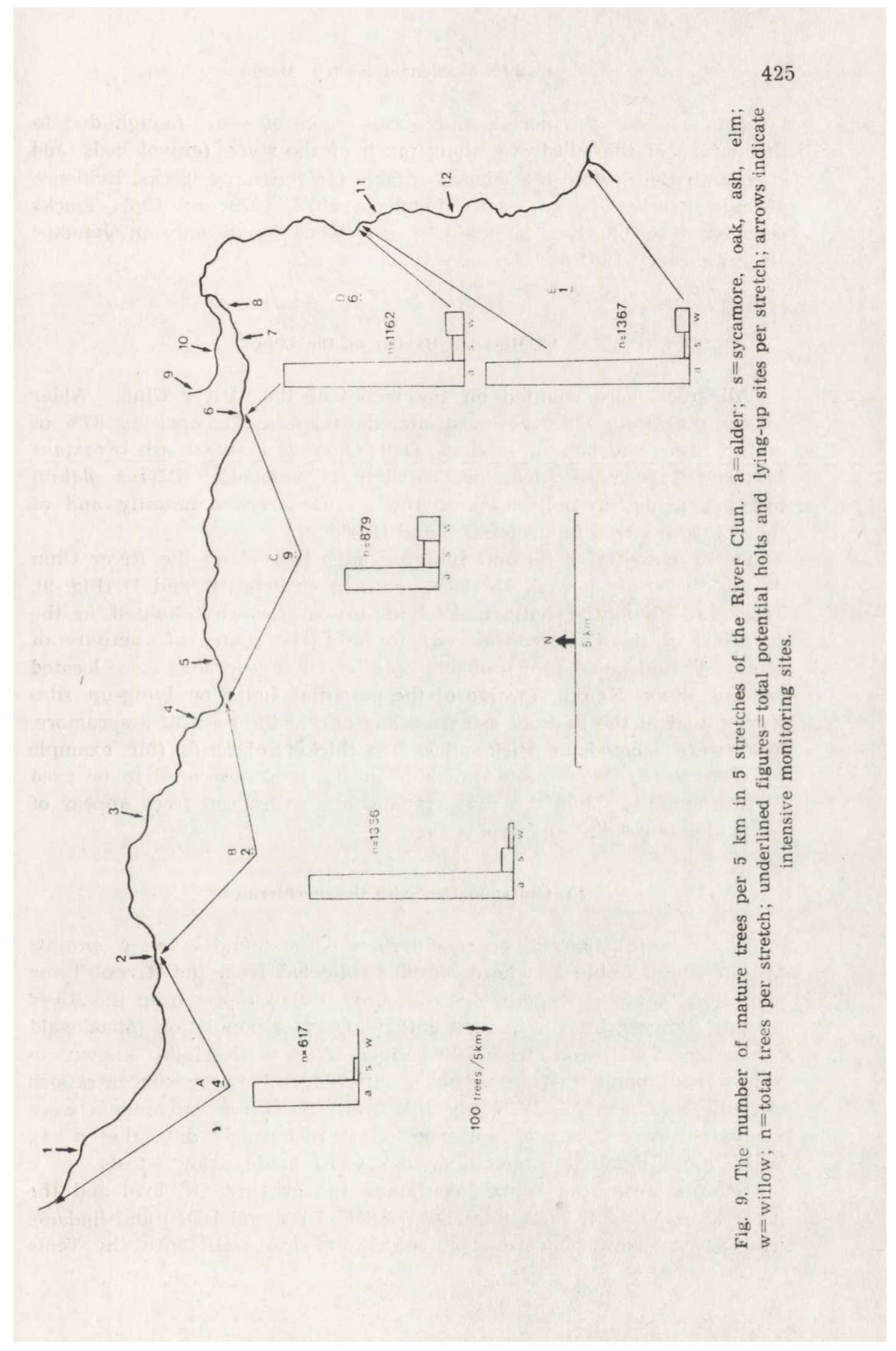


larly throughout the period and at all times of year, though due to the nature of the substrate along much of the river (gravel beds and grassland) there were few places suitable for recording tracks. Evidence of cubs (tracks $<4.5 \mathrm{~cm}$ ) were found in 1978, 1979 and 1981. Tracks considered to be those males $(>7 \mathrm{~cm})$ were found only in January 1983, Febraury 1984 and January 1985.

\subsection{Riparian Habitat on the Clun}

All trees were counted on the banks of the River Clun. Alder (Alnus glutinosa) was the most abundant species, comprising $87 \%$ of mature trees and $80 \%$ of saplings. Oak (Quercus petraea), ash (Fraxinus excelsior), sycamore (Acer pseudoplatanus) and elm (Ulmus glabra) together made up only $5.4 \%$ of the mature tree community and of these 55\% occurred in stretches C and D (Fig. 9.)

Of 22 potential holts and lying-up sites located on the River Clun during the study period, $15(68 \%)$ were in stretches C and D (Fig. 9). Thus most potential holts and lying-up sites were situated in the stretches of the Clun considered to form the centre of activity of otters. An additional five probable holts and lying-up sites were located on the River Kemp. Twelve of the potential holts or lying-up sites were found in the roots of ash trees and one in the roots of a sycamore. Five were located in stick piles, 8 in thickets of scrub (for example Rhododendron, Rubus), and one hole in the bank appeared to be used by the animals. Thus the root systems of mature ash trees appear of particular importance on this river.

\subsection{Contamination with Organochlorines}

The concentrations of organochlorines (OCs) found in otter spraints are shown in Table 1, where samples collected from the Rivers Teme and Clun (Teme catchment) are compared with samples from the River Severn (Powys), known to hold a thriving otter population (Macdonald \& Mason, 1987) and from the River Wissey (Norfolk) known to hold a poor population (pers. obs.). Differences between concentrations of individual compounds in spraints from the three catchments were compared by analysis of variance on transformed data $(\log n+1)$, while more detailed intercomparisons were made using $t$-tests.

Samples from the Wissey contained the greatest OC load and the greatest amounts of PCB, total DDT (DDE, DDT and DDD) and lindane. The Severn samples were least contaminated overall, with the Teme 
samples being intermediate, but closer in overall contamination to the Wissey samples. Analysis of variance revealed no significant differences in the concentrations of dieldrin and total DDT in samples from the three catchments $(F=0.86, F=0.94$ respectively, $p>0.05$ ), but both compounds made up a greater proportion of the total OC load in samples from the Severn. There were significant differences in the concentration of lindane between sites $(F=5.64, p<0.01)$. The sample from the Severn contained significantly less lindane then those from the Wissey $(t=5.73, p<0.001)$ and Clun $(t=5.42, p<0.001)$, which were not significantly different from one another $(t=0.95, p>0.05)$. Lindane made up a greater proportion of the total OC load in samples from the Wissey.

Table 1

Concentrations ( $\mathrm{mg} \mathrm{kg}^{-1}$ lipid) of organochlorines in otter spraints from three river catchments. (nd=below limit of detection).

\begin{tabular}{lcccc}
\hline Organochlorine & & Teme & Severn & Wissey \\
\hline Lindane & mean & 1.82 & 0.19 & 2.63 \\
Dieldrin & $\begin{array}{l}\text { range } \\
\text { mean }\end{array}$ & $0.5-5.1$ & $\mathrm{nd}-6.1$ & $\mathrm{nd}-36.5$ \\
Total DDT & range & $\mathrm{nd}-0.8$ & 0.28 & 0.11 \\
& mean & 0.66 & 1.04 & $\mathrm{nd}-1.1$ \\
PCB & range & $\mathrm{nd}-3.7$ & $\mathrm{nd}-50.3$ & $\mathrm{nd}-31.1$ \\
& mean & 5.61 & 0.91 & 7.32 \\
Total & range & $\mathrm{nd}-29.4$ & $\mathrm{nd}-29.3$ & $\mathrm{nd}-32.6$ \\
organochlorine & mean & 10.22 & 2.94 & 15.98 \\
Number of samples & & $1.8-31.1$ & $\mathrm{nd}-50.3$ & $\mathrm{nd}-65.0$ \\
\hline
\end{tabular}

Samples from the three catchments had significantly different amounts of PCB $(F=23.6, p<0.001)$, with the Severn samples containing significantly less than samples from the Wissey $(t=5.14, p<0.001)$ and Clun ( $t=3.71, p<0.001$ ). The difference between means of samples from the Wissey and Clun was not significant $(t=0.61, p>0.05)$. PCB made up a greater proportion of the total OC load in the Teme samples. The three catchments also differed in the total OC loadings of spraint samples $(F=22.0, p<0.001)$, the Severn samples containing significantly less OC than the Wissey $(t=4.65, p<0.001)$ or Teme $(t=2.78, p<0.01)$. Samples from the Wissey and Teme were not significantly different in total OC load $(t=1.62, p>0.05)$.

\section{DISCUSSION}

The study presented here has been based largely on the location and quantification of signs of otters. The value of spraint surveys for 
studies of otters has recently been questioned (Kruuk et al., 1986), but both Jefferies (1986) and Mason and Macdonald (1987) have provided a detailed evaluation of the techniques. Such indirect methods are likely to be the only way of assessing the status and requirements of the many individual otter populations under threat. Alternative methods, such as intensive radio-telemetry studies, will provide results only slowly, because of the large resources required to conduct them, while the results of individual studies will need to be applied with caution to other populations and regions, for it is already apparent that the ecology and behaviour of the otter is very flexible, depending on the prevailing local conditions (Mason \& Macdonald, 1986).

It was necessary to determine the length of time spraints survived on the study sites. The experiment with marked spraints showed a negative exponential rate of loss, with less than $10 \%$ of spraints disappearing in the first two weeks after deposition. As visits to the intensive study site on the Clun were generally less than two weeks apart, it was concluded that spraints recorded were a good measure of spraints deposited. There appeared to be no advantage in attempting to apply correction factors for loss, as was done by Jenkins and Burrows (1980). These authors recorded a linear disappearance of spraints from their study site in north-east Scotland, with $40-60 \%$ of spraints disappearing within the first two weeks of deposition. It may be that our study sites were more sheltered than those of Jenkins and Burrows (1980), but the criteria of loss were also different. Jenkins and Burrows (1980) considered a spraint to have disappeared if there were too few fragments to be worth collecting. Our criterion of loss was for complete disappearence; even a few fragments of old spraints can smell of otter to the human nose and thus presumably to other otters. Some spraints in very sheltered positions beneath the roots of bankside trees survived for almost a year.

From the observations presented here we suggest that the population of otters was low and still in decline through much of the study period. The first survey of the catchment indicated that the population was already well below the potential carrying capacity (Macdonald et al., 1978). Otters then appeared to withdraw further from the lower tributaries of the catchment, activity being largely confined to the upper Teme, above Ludlow, and the River Clun, by 1982 (Fig. 2). On the intensive study area, the River Clun, there were significantly fewer signs of otters during the period 1983-1985 (Fig. 3). A possible expansion of range in the catchment occurred after 1985. Further evidence for a poor population is provided by the low level of marking on the River Clun. Three complete searches of the river $(32 \mathrm{~km})$ for 
signs yielded densities of $0.6,1.0$ and 2.0 sprainting sites per $\mathrm{km}$. This can be compared with data from the River Severn, Wales, considered to hold a thriving otter population (Macdonald \& Mason, 1987). Thirty-six surveys over three years of seven $1 \mathrm{~km}$ stretches yielded average spraint site densities of $2.6-10.3 \mathrm{~km}^{-1}$, mean $6.2 \mathrm{~km}^{-2}$ (unpublished data), so even allowing for the marked seasonality in the marking of otters on the Severn (Macdonald \& Mason, 1987), overall marking intensity was considerably higher.

Marking intensity can be further explored by examining the number of signs deposited at each sprainting site. Over the study period, $60 \%$ of sites on the Clun had only single signs, while only $1 \%$ had more than six signs (Fig. 5). On the River Severn, 36\% of sites had single signs, witht $12 \%$ more than six signs (unpublished data). The difference in frequency distribution of number of signs and sprainting sites on the Clun and Severn is higly significant $\left(\chi^{2}=131, \mathrm{df}=5, p<0.001\right)$. All of these strands of evidence lead us to conclude that the otter population on the Teme catchment was at a lower density than that of the Severn.

On the River Severn there was a distinct seasonality in marking behaviour, most signs being deposited during the winter and early spring, with comparatively few signs during the summer and early autumn (Macdonald \& Mason, 1987). On the Clun no such consistent seasonality was found. More signs were deposited in the late summer ana early autumn period (Fig. 4), at a time when marking on the Severn was low. Such a peak was most apparent only in the years 1978, 1979 and 1981 and it may be significant that it was in these three years that cubs were definitely identified as present on the river. In the Severn study (Macdonald \& Mason, 1987) it was suggested that the winter increase in marking activity could be related to the establishment of dominance hierarchies, resident animals needing to defend their ranges more vigorously at a period when young otters were dispersing. If, as suggested here, the otter population on the Teme catchment was well below carrying capacity, there may be no need for a vigorous defence of ranges, and hence no need for a similar increase in marking activity.

Although there was no distinct seasonality in overall marking intensity, nevertheless there was a clear pattern in the types of signs deposited (Fig. 8). There was a greater proportion of smears deposited during the spring and summer, as there was also on the River Severn (Macdonald \& Mason, 1987) where it was suggested that, if females were with young, there was less need for males to defend ranges. Indeed it may be advantageous to act discreetly at such periods. Anal 
jelly was mostly recorded in the winter period on the Clun and was associated with increased scratching of the substrate. Similarly on the Severn there was a greater proportion of anal jelly deposited in the winter, at a time when scratching, rolling and the production of sign heaps was most obvious (Macdonald \& Mason, 1987). Such signs are likely to be associated with a specific type of behaviour, though we do not know yet what it is.

The majority of signs of otters on the Clun were deposited in the central stretches of the river (Fig. 6) and this was where most potential holts were recorded and where the greatest density of bankside trees occurred (Fig. 9), including ash, sycamore and oak, considered by Macdonald and Mason (1983) to be the most important secure holt sites in this region. This central stretch of river probably formed the centre of activity of the otter population. Such centres of activity have been described for radio-tracked otters in Scotland (Green et al., 1984) and for Lutra canadensis, Schreber, 1776, in Idaho, U.S.A. (Melquist \& Hornocker, 1983). The results of these studies, and that of Jefferies et al. (1986) on otters radio-tracked in East Anglia following release for a restocking projest, emphasize the importance of dense riparian vegetation. Green et al. (1984) found that the majority of tree holts used by otters were ash and sycamore. The relationship between otter distribution and vegetation is described more fully by Mason and Macdonald $(1986,1987)$.

The otter population in the Teme catchment was considered to be considerably below the potential carrying capacity at the start of this study (Macdonald et al., 1978) and to have continued to decline. It is therefore necessary to investigate the causes of this situation. The habitat within the catchment overall was certainly not ideal, but there was no significant destruction of habitat during the study period. The decline in the British otter population as a whole was sudden and has been attributed to the introduction of the pesticide dieldrin into agriculture in the 1950s (Chanin \& Jefferies, 1978). It is likely, however, that PCBs also increased markedly in the environment at this time (Thomann et al., 1986) and Olsson et al. (1981) attributed the steep decline in Swedish otter populations to PCBs, the tissues of many animals containing concentrations of $\mathrm{PCB}$ greater than those known to cause reproductive failure in mink (Mustela vison, Schreber, 1777).

During the study no otters from the Teme catchment became available for tissue analysis for residues, but a male found dead in a neighbouring catchment, the Lugg, contained a PCB concentration in muscle of $112.5 \mathrm{mg} \mathrm{kg}^{-1}$ lipid (Mason et al., 1986), more than twice that known to cause reproductive failure in mink (Jensen et al., 1977). 
To obtain an indication of the OC loading in otters in the Teme catchment, a collection of spraints was analyzed and compared with sample; from the River Severn and River Wissey (Table 1). We have no information on the relationship between OC levels in spraints and effects on otters, but of course there are similar problems in the interpretation of tissue concentrations of OCs without detailed toxicological studies on otters.

The concentrations of total OCs, lindane and PCBs in spraints from the Teme catchment were significantly higher than those from the Severn, holding a thriving otter population. Concentrations of these compounds were lower, but not statistically significantly so, than a sample of spraints from the River Wissey, Norfolk, considered to hold an endangered otter population; three such precarious populations in Norfolk have gone extinct during the 1980 s (pers. obs.). Concentrations of dieldrin and total DDT in the three samples of spraints were not significantly different. Thus, the concentrations of OCs, and particularly PCBs, in spraints from these populations are inversely related to our perceptions of the performance of the three populations. We would therefore suggest that organochlorines are still a potent factor in limiting the distribution of otters.

The concentrations of OCs in spraints could represent the excretion of contaminants accumulated some time ago, or they could indicate sources which are still present in the catchment. Such biomagnifying compounds enter watercourses from a variety of sources (Mason \& Macdonald, 1986) and point discharges from apparently small sources could have significant effects on the fauna of receiving streams.

From observations collected in 1986 and 1987 we have suggested that the otter may be expanding its range again within the catchment, signs of otters being found in stretches where we had not recorded them for nearly a decade. There are three possible sources of colonists. They may be animals reared within the catchment, though we have not evidence of cubs since 1981. They may be animals crossing into the catchment from the headwaters of neighbouring catchments. Otters appear to be expanding in population in a number of areas of Wales (Andrews \& Crawford, 1986), including the Rivers Severn and Wye (Macdonald \& Mason, 1987, pers. obs.), which have tributary headwaters but a few $\mathrm{km}$ krom the Teme. Alternatively, colonists could enter via the confluence of the Teme with the Severn; although otters have not been recorded so far down the Severn in recent years, they are clearly expanding in the upper reaches of the river and in 1987 we found expanding in the upper reaches of the river and in 1987 we found signs regularly many $\mathrm{km}$ downstream of our previous observations. 
sful in the long term and indeed whether the range expands eastwards into the Midlands. Our observations indicate that contamination of watercourses with OCs, particularly PCBs, may still be a potent threat to success.

Further, Jefferies and Hanson (1987) reported a concentration of PCBs of $62 \mathrm{mg} \mathrm{kg}^{-1}$ fat in the liver of an unweaned cub killed by a vehicle. This animal, born of a female released into an apparently pristine nature reserve as part of a restocking programme in eastern England (Jefferies et al., 1986), though less than three months old, already had a PCB load greater than the $50 \mathrm{mg} \mathrm{kg}^{-1}$ fat considered by Jensen et al. (1977) to result in reproductive failure in mink. Such an observation must cast doubt on the wisdom and ethics of re-introduction programmes into areas where otters have recently become extinct.

It is clearly essential to monitor any natural expansion in range of otters, but it is also important to estimate the potential effects of contaminants on success, for example, as here, by measuring their concentrations in spraints.

\section{REFERENCES}

1. Andrews E. L. \& Crawford A. K., 1986: Otter survey of Wales 1984-85. Vincent Wildlife Trust, London, $1-74$.

2. Chanin P. R. F. \& Jefferies D. J., 1978: The decline of the otter Lutra lutra L. in Britain: an analysis of hunting records and discussion of causes. Biol. J. Linn. Soc., 10: 305-328.

3. Erlinge S., 1967a: Food habits of the fish-otter Lutra lutra L. in South Swedish habitats. Viltrevy, 4: $371-443$.

4. Erlinge S., 1967b: Home range of the otter Lutra lutra L. in southern Sweden. Oikos, 18: 186-209.

5. Erlinge S., 1968a: Territoriality of the otter Lutra lutra L. Oikos, 19: 81-98.

6. Erlinge S., 1968b: Food studies on captive otters (Lutra lutra L.). Oikos, 19: 259-270.

7. Food and Agriculture Organization, 1983: Manual of methods in aquatic environmental research. Part 9 - Analyses of metals and organochlorines in fish. FAO Fisheries Tech. Paper 212.

8. Green J., Green R. \& Jefferies D. J., 1984: A radiotracking survey of otters Lutra lutra on a Perthshire river system. Lutra, 27: 85-145.

9. Her Majesties' Stationery Office, 1979: Organochlorine insecticides and polychlorinated biphenyls in waters, 1978. HMSO, London.

10. Jefferies D. J., 1986: The value of otter Lutra lutra surveying using spraints: an analysis of its successes and problems in Britain. Otters: The Journal of the Otter Trust, 1(9): 25-32.

11. Jefferies D. J. \& Hanson H. M., 1987: The Minsmere otter release and information gained from a detailed examination and analysis of the two casualt.es. Otters: The Journal of the Otter Trust, 2(1): 19-29.

12. Jefferies D. J., Wayre P., Jessop R. M. \& Mitchell-Jones A., 1986: Reinfor- 
cing the native otter Lutra lutra population in East Anglia: an analysis of the behaviour and range development of the first release group. Mammal Rev., 16: 65-79.

13. Jenkins D. \& Burrows G. O., 1980: Ecology of otters in northern Scotland. III. The use of faeces as indicators of otter (Lutra lutra) density and distribution. J. anim. Ecol., 49: 755-774.

14. Jenkins D. \& Harper R. J., 1980: Ecology of otters in northern Scotland. II. Analyses of otter (Lutra lutra) and mink (Mustela vison) faeces from Deeside, N.E. Scotland in 1977-78. J. anim. Ecol., 49: 737-754.

15. Jensen S., Kihlstrom J. E., Olsson M., Lundberg L. \& Orberg J., 1977: Effects of $\mathrm{PCB}$ and DDT on mink (Mustela vison) during the reproductive season. Ambio, 6: 239.

16. Kruuk H., Conroy J. W. H., Glimmerveen U. \& Ouwerkerk E. J., 1986: The use of spraints to survey populations of otters Lutra lutra. Biol. Conserv., 35: $187-194$.

17. Macdonald S. M. \& Mason C. F., 1983: Some factors influencing the distribution of otters (Lutra lutra). Mammal Rev., 13: $1-10$.

18. Macdonald S. M. \& Mason C. F., 1987: Seasonal marking on an otter population. Acta theriol., 32: $449-461$.

19. Macdonald S. M., Mason C. F. \& Coghill I. S., 1978: The otter and its conservation in the River Teme catchment. J. appl. Ecol., 15: 373-384.

20. Mason C. F., Ford T. C. \& Last N.I., 1986: Organochlorine residues in British otters. Bull. Environ. Contam. Toxicol., 36: 656-661.

21. Mason C. F. \& Macdonald S. M., 1986: Otters: ecology and conservation. Cambridge University Press, Cambridge. 1-236.

22. Mason C. F. \& Macdonald S. M., 1987: The use of spraints for surveying otter Lutra lutra populations: an evaluation. Biol. Conserv., 41: 167-177.

23. Melquist W. E. \& Hornocker M. G., 1983: Ecology of river otters in west. central Idaho. Wildl. Monogr., 83: 1-60.

24. Olsson M., Reutergardh L. \& Sandegren F., 1981: Var ar uttern? Sveriges Natur, 6/8: 234-240.

25. Thomann R. V., Connolly J. P. \& Thomas N. A., 1986: The Great Lakes ecosystem-odelling the fate of PCBs [In: Waid, J. S. (ed.), PCBs and the environment] vol. III: 153-186. CRC Press, Boca Raton.

Received 4 March 1988, Accepted 19 May 1988. 


\section{Sheila M. MACDONALD i Christopher F. MASON}

\section{OBSERWACJE NAD POPULACJA WYDRY WYKAZUJACA SPADEK LICZEBNOSCI}

\section{Streszczenie}

Rejestracja rozmieszczenia śladów obecności wydry, Lutra lutra (Linnaeus, 1758) w zlewni rzeki Teme w Wielkiej Brytanii (Ryc. 1), w okresie 10-letnim wykazała, że zasięg gatunku ograniczony już na początku badań w 1977 roku nadal kurczył się w następnych latach. Występowanie wydr ograniczyło się do górnej części zlewni (Ryc. 2). Przedstawiono dowody na to, że skażenie ogranochloranami (pochodzącymi z odchodów wydr) mogło być odpowiedzialne za spadek liczebności. Dyskutowane są również przyczyny prawdopodobnego wzrostu rozprzestrzeniania wydry w ciągu ostatnich lat badań.

Regularne obserwacje miejsc, w których wydry zostawialy kal na rzece Clun (dopływ Teme) wykazały, że tempo zanikania śladów zostawionych przez wydry miało charakter ujemnej funkcji wykładniczej, $90 \%$ śladów było ciągle obecnych po 2 tygodniach. Poziom znakowania areałów na rzecze Clun sugerowal niską liczebność populacji wydry (Ryc. 5). Nie obserwowano wyraźnej sezonowości w znakowaniu kałem, typowej dla dobrze prosperujących populacji (Ryc. 4). Nasilenie znakowania zmalało w ciągu okresu badań (Ryc. 3). Zaobserwowano jednak sezonowość różnych rodzajów znakowania.

Większość śladów obecności wydry na rzece Clun zlokalizowano w centralnej części rzeki, która charakteryzowała się największą ilością roślinności brzegowej.. 